neighborhood, and even the law-makers of the land, were no better off, and yet her heart sang for joy.

For right down in her warm mother's heart she knew that this discipline, these trials and hard struggles, were making a man of her boy; that poverty could not harm him, but would train him to habits of economy and industry; that few bad habits grow without money as a fertilizer; that he,

"By poverty kept to his daily task,

And by bis daily task to virtue kept,"

would grow up an honorable, upright, useful man; and so "with health and hope and faith in the dear Father over all, caring for His own, why should she not smile and be glad?

\title{
LIFE AND DEATH OF THEODORE GUELICH.
}

\section{BY B. H. GUE.}

Theodore Guelich, who died at Burlington, on the $27^{\text {th }}$ of January, 1893, has been for more than thirty years one of the notable men of Iowa. Hè was born in Schleswig-Holstein, January 29th, 1829. He began the usual thorough course of - education common to the ambitious German youth, and was preparing for entrance into one of the best Universitics when the revolution of 1848 began. He espoused the cause of the revolutionists with all the ardor of a freedom-loving young student, entered the army and served with great gallantry for three years. He was several times wounded in the heroic struggles which his countrymen were making for freedom from their oppressors, and when defeat finally came, he with many others sought a new home in the American Republic, beneath the protection of the stars and stripes that Baron . Steuben and other gallant German patriots had fought under in the dark days of the Revolution of 1776.

He settled at Davenport in i $8 ; \mathrm{I}$, and soon after established Der Democrat, a weekly journal which took high rank among the German papers of the West. While publishing his paper, Mr. Guelich found time to study the English language and law, and in 1856 he had matde such progress that he was 
admitted to the bar, and entered upon the practice of his new profession while still editing and publishing his paper.

$\mathrm{He}$ at once took strong ground against American slavery, and was earnest and outspoken in denunciation of the outrages perpetrated upon the early settlers in Kansas by the organized bands of "Border Ruffians," who sought to establish slavery in that new Territory.

Although he had advocated the election of Franklin Pierce to the Presidency in 1852 , he fearlessly condemned his administration when it sought to extend slavery into the free western Territories. He was one of the leaders in the anti-slavery movement in the West, which resulted in the organization of the Republican party.

When the great rebellion of 1861 threatened to overthrow the American Republic, which had long been the refuge of the oppressed of the old world, and President Lincoln issued his first call for volunteers to preserve the Union. Theodore Guelich, without a moment's hesitation, enlisted in the ist Iowa Regiment of Volunteers, on the day the President's proclamation appeared.

$\mathrm{He}$ was chosen: Ist Lieutenant of Company " $G$," and the regiment was mustered into the U. S. service May gth, I86I. On the 16th Mr. Guelich was promoted to Quartermaster. He was in the battles of Wilson Creek, Belmont, and other fierce engagements, was a gallant soldier and an accomplished and efficient officer.

Shortly before the beginning of the rebellion, Mr. Guelich had removed to Burlington and established the Iozva Tribnene, a German paper, and entered upon the practice of law. At the close of the war he returned to that city and resumed his work in both professions with marked success. Mr. Guelich was not only an able editor of his own paper, but was a frequent contributor to some of the leading journals of the State, upon topics in which he felt a deep interest. He was a writer of the best style of English, and a powerful antagonist in the numerous discussions that he had on subjects of legislation, upon which he held decided opinions. He always maintained his views with rare vigor and ability. He was a 
scholar and a gentleman in all his controversies, and in solid argument and close reasoning he had few equals among Iowa journalists.

When the Republican party was organized in Iowa for the union of all citizens opposed to the extension of slavery, Mr. Guelich was one of the most determined and eloquent advocates of leaving out of its declaration of principles all minor issues upon which the anti-slavery people were divided in opinion. He, with Hon. James Thorington, Nicholas J. Rusch, Samuel J. Kirkwood and other wise and patrintic leaders, insisted upon the adoption of the national platform, which had consolidated into one party all who held the paramount issue to be opposition to the aggressions of the slave power. Many earnest and sincere men in Iowa strongly urged upon the first Republican State Convention the endorsement of prohibition of the liquor traffic, which was then a live issue in State legislation, and a large body of the anti-slavery wing of the old Whig party as strongly urged a declaration for a protective tariff. But it was urged by Guelich, Thorington, Kirkwood and others, that upon the one broad principle of opposition to the aggressions of the slave power, a powerful and invincible party could be organized, embracing men of diverse views on tariffs, national banks, Know Nothingism, prohibitionism, etc. But, if an attempt was made to incorporate such minor issues in the platform, union was impossible, and defeat of the one great cause of national freedom would be inevitable.

There were no more earnest opponents of human slavery in America than the thousands of Germans who had left their native land to make new homes in a foreign country, to enjoy the larger freedom which a republican government guaranteed to its citizens; and their opposition to prohibition was as nearly universal as was their love of freedom and hatred of human bondage. The founders of the Republican party in Iowa wisely held the minor issues in abeyance, and organized on the broad national platform, upon which all anti-slavery people could stand and work together with hope and enthusiasm. So long as Iowa Republicans stood on the old national platform 
alone, Mr. Guelich was one of its ablest leaders and most: devoted supporters. But when it indorsed prohibition his. opposition to such encroachments upon "personal liberty," as. he termed it, was so decided that he left the party with. thousands of his German fellow-citizens, and united with the Democratic party in a crusade against the Iowa prohibitory. law. However much his old friends and associates in antislavery days may have differed with Mr. Guelich in later years, none of them ever questioned his sincerity or motives.

He was the soul of honor, but an independent thinker, andl had the courage to go where his judgment, reason and extreme love of personal liberty led him, as in youthful days: he risked his life in two wars for freedom from oppression.

Although a wise counselor and trusted leader in the Republican party for a quarter of a century, he never sought office, always preferring to work in the ranks. Later in life, when he transferred his allegiance to the Democratic party, he was chosen Chairman of the State Central Committee, and: served with marked ability.

Last year he was appointed a member. of the Iowa Columbian Commission, to fill a vacancy caused by the death of Judge Edward Johnstone.

On the morning of January 27 th he dropped dead in his: home from heart disease, without any previous sickness. . He was stricken down in the meridian of life, in the full vigor of his strong manhood, passing instantly from a career of great usefulness and all of its varied responsibilities, into the life beyond.

I have known him well for more than forty years, and in the early days of the anti-slavery movement, was often intimately associated with him in political affairs and contests. I remember him as a young man endowed with strong intellectual powers, always cool and self-possessed, of excellent judgment, a vigorous writer and courageous leader, a manly, conscientious worker for what he believed to be right.

He never truckled to power or wealth, but maintained a sturdy independence, that won for him the respect of all honest people. He was not hasty in reaching conclusions. 
He carefully weighed the reasons for or against a proposition, and when he had finally made his decision and mapped out his path of duty, he pursued it with an iron will that no considerations of personal benefits could swerve.

An intimate friend writes of him in the Burlington Hazokeye:

"He was a representative of the highest type of citizenship. Public spirit was strong in him at all times, strong even to the sacrifice of self on many occasions when the necessity came to chose between the performance of what he considered a duty to the public, or the furtherance of personal interest. On more than one occasion the writer has known him to turn his back upon his private professional work for weeks, even months at a time, suffering not inconsiderable losses, when he had engaged in an undertaking of a public character, political or otherwise. And all this without the thought of personal reward, simply from a sense of duty, that permitted him not to rest until the self-imposed task was completed. He would gratefully and kindly accept a pleasant word in recognition of his services, but as to accepting any recompense of a substantial character, for himself, he spurned such an idea with scorn. He was ever ready to help a friend, and insist that others get their dues, but he was too high-minded to give any one the smallest occasion to think that for his work in behalf of the public, he could possibly have looked forward to compensation. Indeed, had Theodore Guelich done as most men think proper to do, and had he demanded, as he had a right to demand, and accepted that recognition for his political services which they merited, he would have made a remarkable career indeed.

To his public-spiritedness, to his many virtues as a model citizen, the press of Burlington has unitedly taken occasion to pay glowing tributes since the hour of his death, and every word of encomium that has been said in honor of his memory - is finding a responsive echo in the hearts of his fellow-citizens. All feel that by his sudder departure to the other shore they have sustained a loss. Yet how much greater is this loss to the limited number of those who stood in close relation to him. For, known by all, friendly to everybody, accessible 
at all times to any one seeking his kind counsel or assistance, it is nevertheless true that but very few really intimately knew the remarkable character of this man. The tumultuous period in which he passed those years of his youth, during which the character of the coming man is formed, had left an imprint on his nature, and disappointments in later years had served to give him a certain reserve and reticence of manner which often led those who did not know him well, to consider him proud, or harsh and austere. But he was neither. $\mathrm{He}$ did not care to unfold the innermost sides of his disposition to every one. That was all-and it was not everybody, therefore, who was privileged to know his charming nature. Far from lacking in courtesy-he was really the most courteous of gentlemen, one who did not indulge in studied phrases, but found it absolutely impossible to do or say anything to wound the feelings of others or make them feel ill at ease in his presence. A story of grief, or suffering, or sorrow, always found him a willing listener. The needy ever found him ready to extend a helping hand.

A leading trait of his character was the love of right and justice. In pursuance of what he considered right, he spared not himself nor others. He rigidly followed the path of duty, as he saw it, turning neither to the right nor left.

When he, the enthusiastic Republican leader, left the party that he had grown up in, whose principles he had dearly loved, it was not without many pangs, and only after months of anxious meditation. It took a long and bitter struggle with himself before he came to the conviction that it was his duty as a believer in personal liberty. to associate himself with the other party which he had opposed so long and bitterly. But having once made the change, he became just as earnest. just as loyal in his defense of the new political connection, as he had been in that of the old.

His ability as a writer is too well known to need any special mention. A thinker by nature, he had the faculty of expressing his thoughts in forcible and convincing language, marked by brevity and elegance. There are few of his 
nationality who acquire so complete a mastery of English as he possessed.

He was a man whom it was an honor to know, and a privilege to count as a friend. He would have achieved greatness had he sought it. His life was memorable and successful, as he always tried to be helpful to others."

Of the members of the United States Senate in that memorable long session of 1850 , I have as yet been able to trace but one, as still living and voting in this weary world. I have followed some quite fresh tracks quite hopefully till they suddenly brought up before a barrier of granite or marble, a closed gateway, shaded hy yews, and flanked by inverted torches. Senator and General George Wallace Jones, of Iowa, a hero of, the Black Hawk War and several affairs of honor, who must be pretty far down on the sunset side of fourscore, was a notable and gallant figure here during the Grand Army Encampment, and is again visiting the Capital, where he impresses. all who meet him by his wonderful vigor, physical and mental. In 1850 he was a handsome, elegant man, very dark, and with an abundance of tightly curling; black hair, yet no abolitionist for all that. He hás still his manly beauty, his tall, erect figure, his elastic step, the charm of his smile and conversation. $\mathrm{He}$ has even kept his pretty curls; but he wears them powdered now.-Grace Greenzuood, in The N. Y. Independent.

In early days there was a paper town by the name of Win-. field, near the mouth of Duck Creek, in Scott county, which was one of Davenport's competitors for the county seat. The Winfield people offered to donate ninety acres of ground and $\$ 825$ to the county if their prospective town was chosen. But Davenport raised the bid to $\$ I, 200$ and numerous town lots, and won the county seat. The "Winfield corn field" thus. narrowly escaped becoming a city. 
Copyright of Annals of Iowa is the property of State of Iowa, by \& through the State Historical Society of Iowa and its content may not be copied or emailed to multiple sites or posted to a listserv without the copyright holder's express written permission. However, users may print, download, or email articles for individual use. 